\title{
The Detective Physician
}

The Life and Work of Sir William Willcox, 1870-1941

P. H. A. Willcox, M.A., M.D., F.R.C.P.

William Willcox was one of the great figures in the medical profession of his time, and this fascinating biography by his son reveals him not only as a brilliant forensic scientist (he was involved in the Crippen case) but also as a medical seer and consistant searcher after truth and justice both in professional life and in the courts of law.

344 pages Royal 8vo 16 illustrations $€ 3.50 \quad 70$ s net

Napoleon's Surgeon

J. Henry Dible, M.B., Ch.B., LL.D., F.R.C.P.

In this fascinating book Professor Dible has annotated the memoirs of

Baron Larrey, Surgeon-in-Chief to Napoleon, of whom the Emperor said 'C'est I'homme le plus verteux que j'ai connu'.

368 pages Royal 8vo 32 pages of illustrations $£ 6.00 \quad$ I20s net

WILLIAM HEINEMANN MEDICAL BOOKS LTD

23 BEDFORD SQUARE, LONDON, WCIB 3HT

Publications of

THE WELLCOME INSTITUTE OF THE HISTORY OF MEDICINE

General Editor: F. N. L. Poynter, Ph.D., D.Litt., Hon.M.D.(Kiel)

Historical Monograph Series, No. 18

\section{THE HISTORY OF CORONARY HEART DISEASE}

\section{by}

\section{J. O. LEIBOWITZ}

(pp. xvii, 227, illus., price $£ 3$, post free)

\section{Obtainable from}

The Wellcome Institute of the History of Medicine,

183 Euston Road, London, N.W.1.

or any bookseller. 


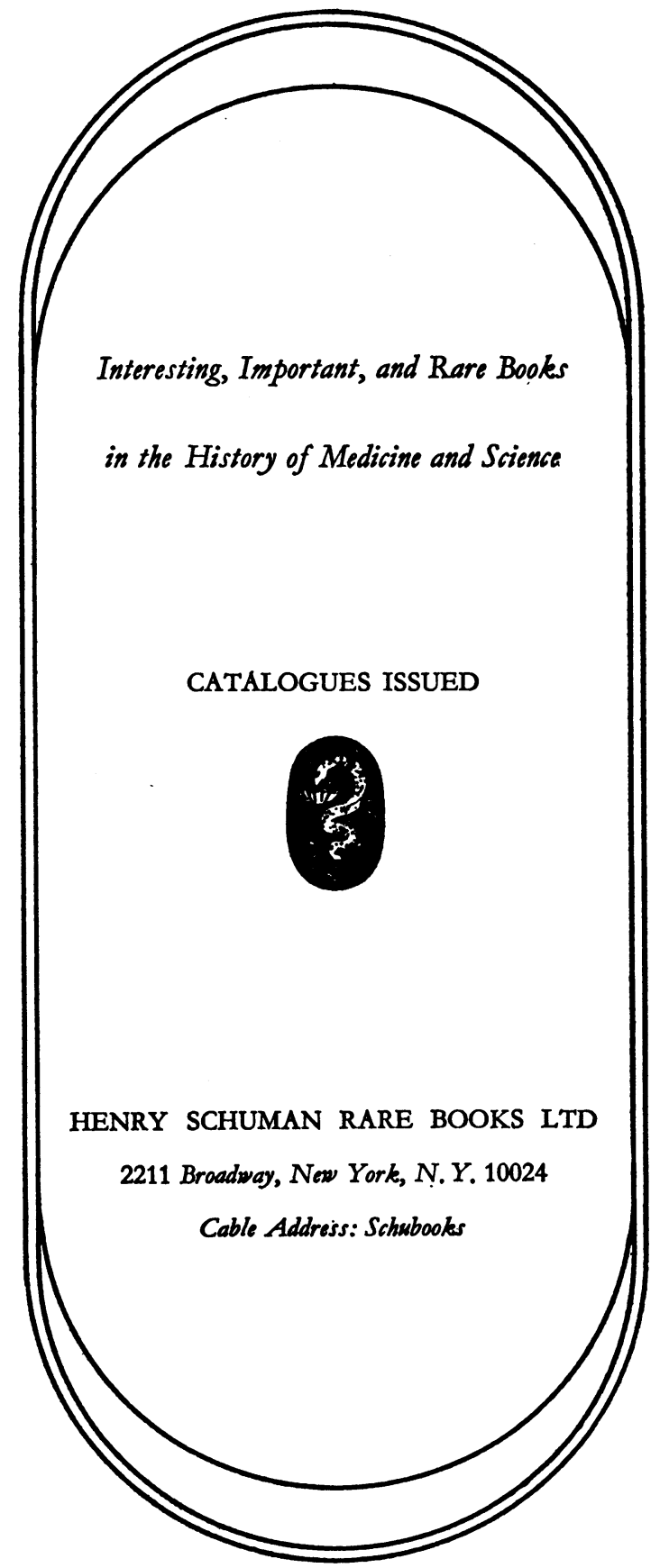




\section{Medical Books}

\section{Prints Manuscripts Portraits}

Old, RARe, \& OUt-Of-Print

\section{America's Largest Stock}

A vast stock, fully catalogued and classified, American and European, dating from $X V-X X$ Centuries, particularly classical and unusual works, with emphasis upon history, biography, and specialized medicine. Lists issued in all fields of medicine. Permanent back-order files maintained.

\section{ARGOSY BOOK STORES}

116 E. 59th St., N.Y. 10022, PL. 3-4455
Books on the History of Medicine and Dentistry Rare Books

We purchase collections Are you on our mailing list?

\section{RITTENHOUSE MEDICAL BOOK STORE}

1706 Rittenhouse Square, Philadelphia, Pennsylvania 19103 Area Code: $215 \quad$ Kingsley 5-4274

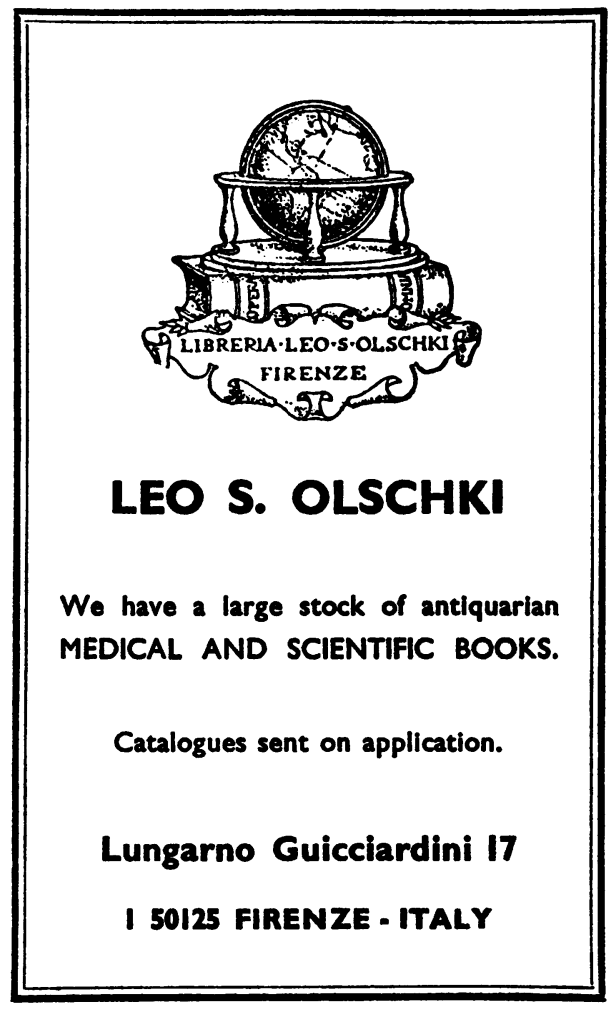

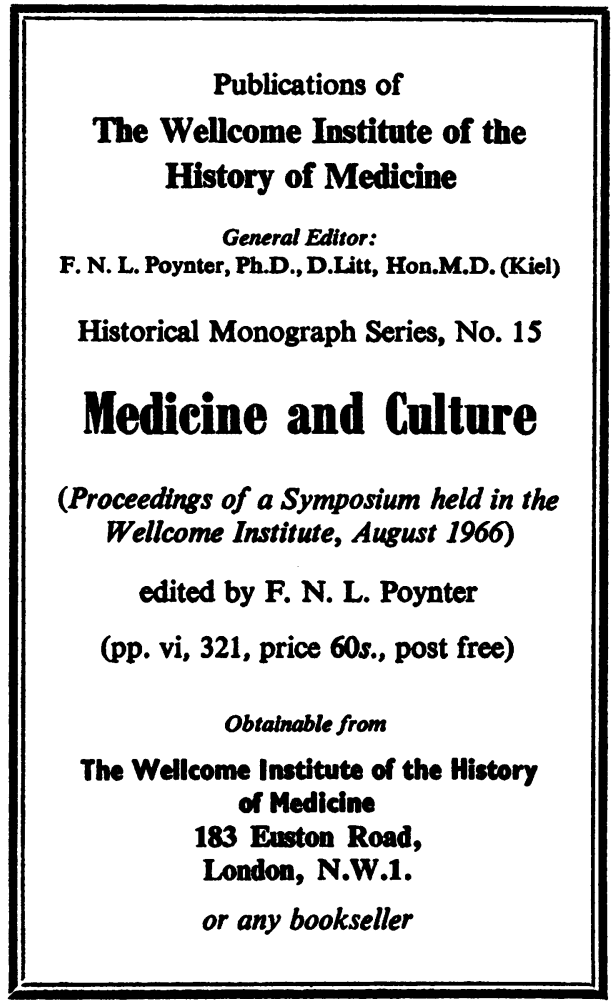

